\title{
Investigation of the Effects of Liquid LPG Use in a Gasoline Injection Turbocharged Engine
}

\author{
Salih Özer ${ }^{1 *}$ and Bahtiyar Bağatur ${ }^{1}$ \\ 0000-0002-6968-8734 1, 0000-0002-8398-9170 2 \\ ${ }^{1}$ Mechanical Engineering Department, Faculty of Engineering and Architecture, Mus Alparslan University, Muş, 049010, Turkey
}

\section{Abstract}

This study examines the effects of starting a vehicle with a turbo-direct gasoline injector (T-GDI) engine with liquid LPG on engine torque and exhaust emissions $\left(\mathrm{CO}, \mathrm{CO}_{2}, \mathrm{HC}\right.$, and $\mathrm{O}_{2}$ ). Vehicle experiments were conducted on a chassis dynamometer. For this purpose, the vehicle was operated with pure gasoline and liquid LPG at engine speeds of 2000, $2500,3000,3500,4000$, and $4500 \mathrm{rpm}$, and the change of all values of each fuel is recorded. The results showed an increase in engine's torque and engine power, along with liquid LPG. Besides, $\mathrm{CO}, \mathrm{HC}$, and $\mathrm{O}_{2}$ emissions decreased, while $\mathrm{CO}_{2}$ emissions increased.

Keywords: LPG, T-GDI, Engine Performance, Exhaust Gas Emissions, New Generation LPG systems

\section{Research Article}

https://doi.org/10.30939/ijastech..914009

$\begin{array}{ll}\text { Received } & 12.04 .2021 \\ \text { Revised } & 22.05 .2021 \\ \text { Accepted } & 25.05 .2021\end{array}$

* Corresponding author

Salih ÖZER

s.ozer@alparslan.edu.tr

Address Mechanical Engineering Department, Faculty of Engineering and Architecture, Mus Alparslan University, Muş

Tel: +903122028653

\section{Introduction}

Many countries are trying to address growing energy demands by using petroleum-derived fuels. But in the near future, fossil resources are in danger of extinction. For this reason, global markets are looking for different renewable, sustainable, low cost, domestic and more environmentally friendly energy sources. Because reasons such as the depletion of fuel reserves of petroleum origin and the increase in air pollution due to their use threaten the entire world [1]. For this purpose, the main agenda issues of the countries focus on the search, supply and use of alternative fuels that pollute the environment less. Air pollution, especially caused by transport, industry, heating and housing, significantly endangers life [2]. Harmful greenhouse gases such as carbon monoxide (CO), hydrocarbon (HC), nitrogen oxides (NOx), particulate matter (PM), sulfur dioxide $\left(\mathrm{SO}_{2}\right)$, volatile organic matter (VOS) and carbon dioxide $\left(\mathrm{CO}_{2}\right)$, which are one of the causes of air pollution in the transport sector, negatively affect life [3]. Many academic studies have been conducted on alternative fuels that can be used in both compression ignition engines (CI) and spark ignition engines (SI) to minimize these harmful gases coming out of vehicles exhausts. Researchers who continue their experimental studies on this sub- ject have been searching for different chemicals in addition to conventional alternative fuel additives that have been accepted thanks to developing technologies. First alternative fuel study in diesel engines. Diesel started the diesel engine using peanut oil. These alternative fuel studies, dating back to ancient times, are further differentiated today [4].

In recent years, the use of alternative fuels in internal combustion engines has focused on biomass fuels (alcohols, vegetable oils, biodiesel), gas fuels (LPG, CNG, acetylene, hydrogen) [5, 6]. Some of the alternative fuels can be used directly in the engine, while some can also be used by mixing gasoline and diesel into their main fuels in various proportions. Alternative energy sources in the sector in the use of LPG (liquefied petroleum gas), CNG (compressed natural gas), LNG (liquefied natural gas), $\mathrm{H}_{2}$ (hydrogen), ethanol and biogas, such as eco-friendly fuels research continues to gain momentum [7]. In gas fuels, fuels such as LPG and CNG have also become commercial products. From this point of view, some vehicle manufacturers have started to produce LPG vehicles from the factory. Because LPG reduces harmful gases from exhaust emissions [8].

The use of LPG as fuel in internal combustion engines, in particular, is based on the following foundations; 
-High octane count,

-High thermal efficiency,

-Be cheap,

-Being produced or supplied from many sources,

-Reduction of emission values [9].

With the popularization of Euro norms, fuel consumption of vehicles and combustion emissions gained great importance. In addition to tracking combustion inside the engine, especially in order to reduce emissions and reduce fuel consumption, post-combustion emissions also began to be tracked. Combustion in gasoline engines, especially in Euro 4 and then Euro 5 norms, began to be provided according to emissions. In this way, the fuel \& air mixture in the cylinder became very important [10]. Using vehicles with LPG fuel is the step taken toward reducing harmful gases from exhaust emissions. It shows that LPG fuel is an alternative fuel with fewer emission values than gasoline. The boiling point values of gasoline and diesel fuels from liquid fuels are above room temperature, while the boiling point values of LPG fuel are at lower temperatures [1]. As LPG fuel moves towards becoming an alternative fuel to gasoline, it can be used without significant changes on spark plug ignition engines. In addition to all these, its economy increases the demand for LPG fuel in the automotive sector. The use of LPG as an alternative fuel in commercial and passenger vehicles has become widespread in Europe and Turkey [11]. Currently, companies sell vehicles with an LPG fuel system that has been installed directly in factories [8]. LPG fuel is sent to the vehicle cylinders by mixing with air in the gas state, so the use of LPG fuel in vehicles also has an impact on vehicle performance. This effect on engine power is lower than that used with pure gasoline fuel [12]. LPG fuel is more environmentally friendly than gasoline and diesel fuel used in internal combustion engines when evaluated in terms of vehicle exhaust emissions, as well as being economically cheap, high thermal efficiency and octane number increase interest in LPG every day.

Demirci and Sycamore [9], examined the effects of pre-mixed compressed CNG use on engine performance and exhaust emissions in a single-cylinder, four-stroke, diesel engine converted to HCCI-DI system. According to the results of their tests, they found that the use of an HCCI-DI engine with CNG under full load provided significant improvements in $\mathrm{CO}$, specific fuel consumption and is emissions, leading to an increase in NOx and HC emissions.

In their study, Saputro and Garcia [13], evaluated performance results in a single-cylinder water-cooled diesel engine with a power of $8 \mathrm{HP}$ by mixing diesel and LPG fuel in certain proportions. In order to analyze the results of the mixture properties in the air intake manifold of LPG fuel, they performed simulation using computational fluid dynamics. They tried performance reversals by increasing LPG fuel to the inlet air by $5 \%$ from $20 \%$ to $40 \%$ and achieved the best result when mixing 30\% LPG fuel.

Zhu et al., [14], four-cylinder four-stroke turbo petrol direct injection (TGDI) engine Cold start studied the combustion and emission values of the turbocharged direct gasoline injection engine under the new European Driving Cycle (NEDC). According to the test results of their study, the combustion duration and the beginning of combustion of 50\% up to cold start position under the new European driving cycle combustion has changed a little, in the first stage of the new European Driving Cycle, the timing of the spark for the delay in the effect of cold running $\mathrm{HC}$ emissions is limited, however, HC emissions of the engine showed a specified average effective pressure) is decreasing due to deceleration cast in a significant way under the conditions they observed. They found that $\mathrm{CO}$ emissions seem to have no interest under cold operation and are too sensitive to excessive air coefficient, while NOx emission values increase in acceleration cases and decrease in deceleration cases, which is mainly affected by the stated average effective pressure and then the speed of the engine.

In his experimental study, Kunt et al., [15], investigated the effects of LPG fuel and gasoline fuel on engine performance and exhaust emissions on a single-cylinder air-cooled, four-stroke gasoline engine. According to the test results, the average engine torque and engine power decreased by $4.15 \%$ compared to gasoline fuel, the average specific fuel consumption decreased by $16.45 \%$ and the average fuel consumption decreased by $16.77 \%$ when LPG fuel was used in the experimental engine. It also found that $\mathrm{CO}$, $\mathrm{CO}_{2}$ and $\mathrm{HC}$ emission values decreased by $35 \%, 2.5 \%$ and $35.36 \%$ respectively compared to gasoline fuel use when LPG fuel was used in the experimental engine, and NOx emission values increased by $88 \%$.

Beak et al., [16] compared the effects of liquid LPG on emissions with diesel used as fuel in a commercial vehicle with a EURO 6 engine. They performed their vehicle experiments on the chassis dynamometer without changing the original exhaust system of the vehicle. For experiments in the chassis dynamometer, they used the World Harmonized vehicle Cycle (WHVC) standard vehicle cycle. For this purpose, the researchers recorded the data by first experimenting with diesel fuel. They then compared exhaust gas emissions $\left(\mathrm{SO}_{2}, \mathrm{C}_{3} \mathrm{H}_{3}, \mathrm{NH}_{2}, \mathrm{THC}, \mathrm{N}_{2} \mathrm{O}, \mathrm{CH}_{4}, \mathrm{CO}\right.$, particulate) with a newly developed LPG direct injection (LPDi) system. Researchers have reported that LPDI fuel is more environmentally friendly than diesel fuel.

Ahn et al., [17] they studied the effects of liquid LPG injection in a vehicle with a turbocharged gasoline direct injection $2.0 \mathrm{~L}$ engine volume. For this purpose, they repeated their experiments with gasoline and liquid LPG by running the vehicle at engine speeds of $1600 \mathrm{rpm}(40 \mathrm{Nm}), 2000 \mathrm{rpm}(75 \mathrm{Nm})$ and $2400 \mathrm{rpm}$ $(110 \mathrm{Nm})$. They conducted their vehicle experiments in the chassis dynamometer. Researchers have stated that liquid LPG fuel reduces all exhaust gas emissions compared to gasoline fuel.

Darzi et al., [18] they studied the effects of adding liquid LPG to the engine to increase combustion efficiency and reduce exhaust gas emissions in a two-stroke air-cooled engine with spark plug ignition. They can control the spray timing with the system they developed to spray liquid LPG at high pressure. In this way, the engine performed the spraying process in different positions of the piston according to the upper dead point. They also repeated their work according to different air excess coefficient. They noted that the air excess coefficient in the addition of liquid LPG is extremely 
important in terms of engine power, engine torque and fuel consumption. They also noted that liquid LPG generates less exhaust gas emissions than gasoline.

As mentioned above, research on the effects of LPG fuel continues and there are many studies on this subject. In this study, unlike other studies, the effects of $100 \%$ liquid phase LPG use on exhaust emissions and engine performance in an experimental vehicle engine with turbo gasoline direct injection system were examined. For this purpose, the T-GDI was first adopted into a vehicle chassis dynamometer. Vehicle 5th we operated it at engine speeds of 2000, 2500, 3000, 3500, 4000 and $4500 \mathrm{rpm}$ while in gear position. Through the Prins LPG system, we can operate the vehicle only with gasoline and LPG. During each vehicle test, engine torque, engine power and exhaust gas emission ( $\mathrm{HC}, \mathrm{CO}, \mathrm{CO}_{2}$ and $\mathrm{O}_{2}$ we record separately values for LPG and gasoline.

\section{Material and Method}

In the experiments, a vehicle with a four-stroke, four-cylinder, turbocharged gasoline direct injection system was used. Technical specifications of the vehicle are given in Table 1. Vehicle experiments were carried out on the chassis dynamometer. Vehicle experiments were conducted on the Dynorace 2WD chassis dynamometer. The dynamometer has a maximum power of $535 \mathrm{HP}$ and a torque absorption capacity of $1500 \mathrm{Nm}$ and the ability to measure up to $300 \mathrm{~km} / \mathrm{h}$ vehicle speed. At each stage of the experimental study, Vehicle Power, vehicle torque and exhaust emission values $\left(\mathrm{CO}, \mathrm{CO}_{2}, \mathrm{O}_{2}\right.$, and $\left.\mathrm{HC}\right)$ were measured and recorded. Exhaust emission measurements a Capelac brand device was used. The measurement range of the exhaust emission device used is given in Table 2. The process of sending liquid LPG to the engine was carried out with the direct LiquiMax liquid LPG model of the company that produces a prince brand LPG kit. With this model, the current injection system of the engine $100 \%$ liquid phase of LPG is sprayed into the cylinder [10]. The image of the control panel of the emission device and chassis dynamometer used during the experiments is shown in Figure 1, and the schematic image of the experimental assembly is shown in Figure 2.

Table 1. Technical specifications of experimental vehicle

\begin{tabular}{c|c}
\hline Vehicle & 1.6 T-GDI DCT 4x2 \\
\hline Engine Type & T-GDI \\
\hline Engine Volume $(\mathrm{cc})$ & 1591 \\
\hline Engine Maximum Speed $(\mathrm{km} / \mathrm{h})$ & 201 \\
\hline Maximum Power $(\mathrm{HP})$ & $177 / 5500$ min-1 \\
\hline Maximum Torque $(\mathrm{Nm})$ & $265 / 4500$ min-1 \\
\hline Injection Type & Direct \\
\hline Number of Cylinder & 16 valve \\
\hline Number of Valves & 7 DCT \\
\hline Transmissions Type & $245 / 45$ R19
\end{tabular}

Table 2. Exhaust emission device specifications.

\begin{tabular}{c|c|c}
\hline Model & Capelec CAP 3201-4 GAZ & $\begin{array}{c}\text { Measurement Accu- } \\
\text { racy }\end{array}$ \\
\hline $\mathrm{HC}$ & $0-20000 \mathrm{ppm}$ Hexan & $\% 1$ \\
\hline $\mathrm{CO}$ & $0-5 \%$ vol. & $\% 0.001$ \\
\hline $\mathrm{CO} 2$ & $0-20 \%$ vol. & $\% 0.1$ \\
\hline $\mathrm{O} 2$ & $0-21,7 \%$ vol. & $\% 0.01$ \\
\hline $\mathrm{NOx}$ & $30-10000 \mathrm{ppm}$ & 1 \\
\hline
\end{tabular}

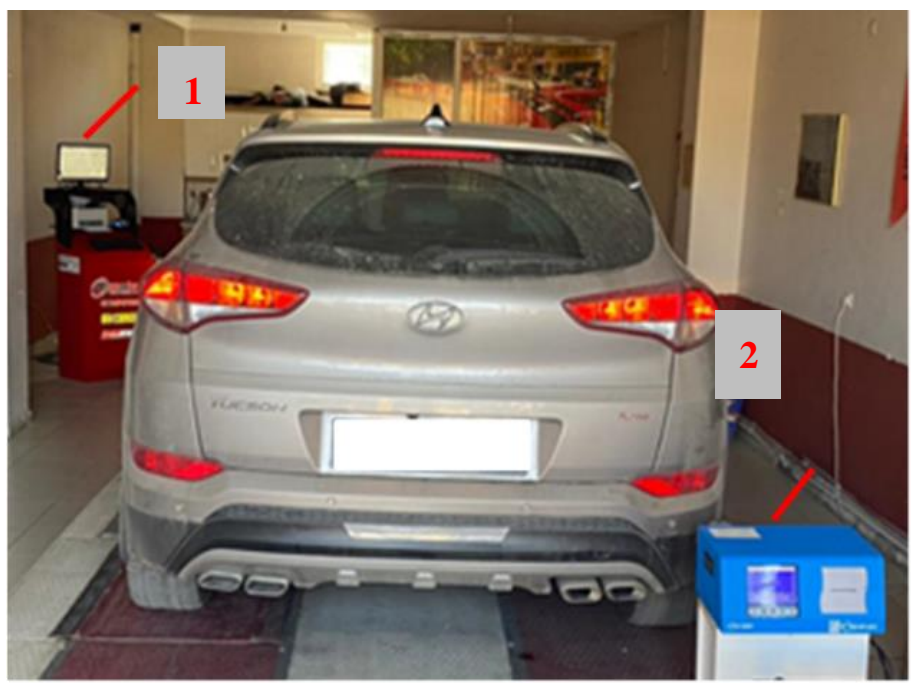

1. Exhaust gas emission, 2. Chassis Dynamometer Control Panel Figure 1. A picture of the experimental assembly.

After the engine water temperature of the vehicle reached $90^{\circ} \mathrm{C}$ and the oil temperature reached $100{ }^{\circ} \mathrm{C}$ for engine experiments, the experiments were started. Engine experiments 5 it was repeated at engine speeds of $2000 \mathrm{rpm}, 2500 \mathrm{rpm}, 3000 \mathrm{rpm}, 3500 \mathrm{rpm}, 4000$ $\mathrm{rpm}, 4500 \mathrm{rpm}$ while in gear lever position.

$$
\text { Climatic Chamber-Imtech }
$$

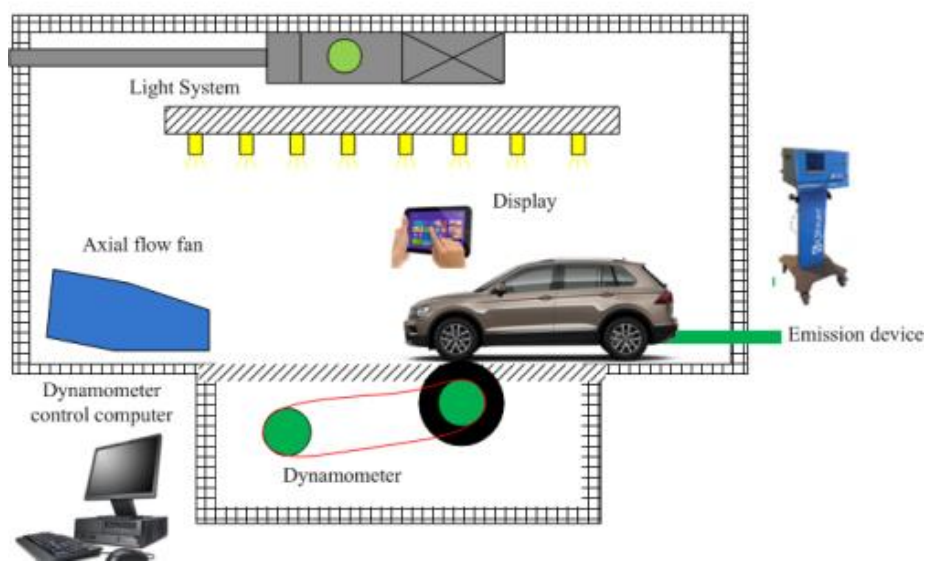

Figure 2. Schematic picture of the experimental assembly. 


\section{Results and Discussion}

Figure 3 shows the effect of changing the use of liquid LPG and gasoline according to engine speed on engine power. An increase in engine power compared to gasoline was observed at all engine speeds when liquid LPG was used. During vehicle experiments, 177 horsepower (HP), the maximum engine power given as the catalog value of the vehicle, was not reached. Only gasoline use was measured with power data of $166 \mathrm{HP}$. With the use of LPG, the maximum engine power increased to $169 \mathrm{HP}$. An increase of approximately $1.7 \%$ in maximum engine power was achieved. It is possible to explain this situation by the fact that the thermal value of LPG by mass is high compared to gasoline. LPG is an advantageous fuel with high octane number. [19]. It is seen in the study results that all the disadvantages that occur when sending LPG into the cylinder as a gas can be overcome by using liquid LPG and sending it directly into the cylinder. In particular, the opinion that the fuel sent with high spray pressure is well atomized and increases combustion efficiency in the cylinder appears in studies. Because LPG, which is sprayed on the air at a high rate with turbo, is thought to provide combustion in a more ideal environment [20].



Figure 3. Change of engine power.

Figure 4 shows the effect of changing the use of liquid LPG and gasoline according to the engine speed on the engine torque. Engine torque occurs as an effect of the pressure on the cylinder as a result of the combustion of the fuel taken into the cylinder. It is an important parameter that allows work in internal combustion engines [9]. Engine torque obtained with LPG is higher up to engine speeds of $2000 \mathrm{rpm}$ and $3500 \mathrm{rpm}$. After the engine speed of 3500 $\mathrm{rpm}$, the torque obtained by LPG decreased and the engine torque obtained by gasoline increased. $210 \mathrm{Nm}$ engine torque was produced with LPG at $2000 \mathrm{rpm}$, while $189 \mathrm{Nm}$ torque was produced with gasoline under the same conditions. The maximum engine torque was $268 \mathrm{Nm}$. $255 \mathrm{Nm}$ engine torque is produced with LPG under the same conditions. As the reason for the increase in engine torque along with the increase in engine speed, it is possible to explain the excessive cooling of the air together with the spraying of liquid LPG in the cylinder. Because liquid LPG will draw heat from inside the cylinder to evaporate, so the end-of-combustion temperature will decrease.

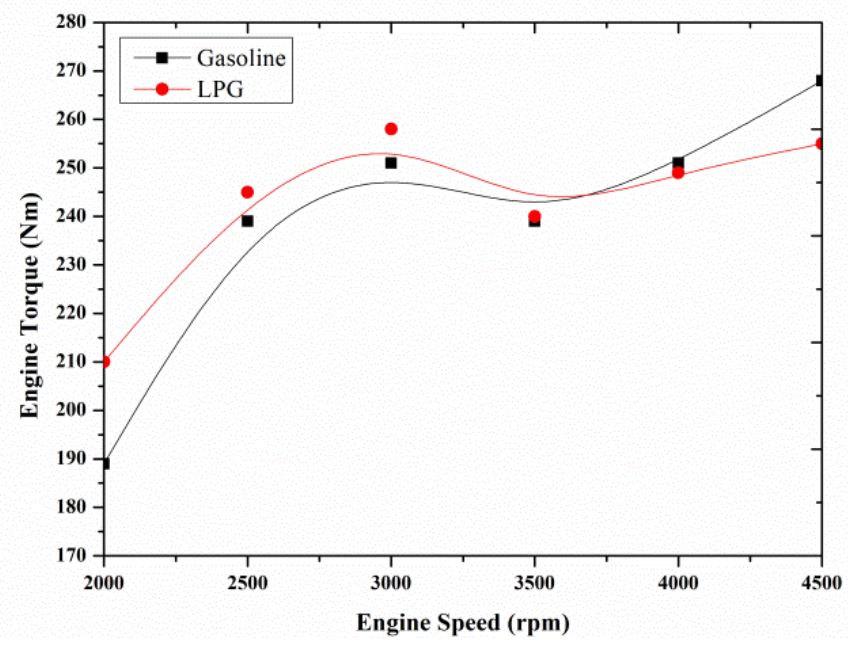

Figure 4. Change of engine torque.

Figure 5 shows the effect of changing the use of liquid LPG and gasoline according to engine speed on $\mathrm{CO}$ emissions. $\mathrm{CO}$ emissions are an incomplete combustion reaction caused by the complete failure of fuels in internal combustion engines. $\mathrm{CO}$ emissions in a turbocharged GDI engine are expected to be less than in other motor vehicles. Because all the air is taken into the engine cylinders to burn the fuel. Despite this, $\mathrm{CO}$ emissions can occur for reasons such as the fact that fuels are not fully atomized, air and fuel do not mix in the cylinder [21]. At all engine speeds, there is a decrease in the use of LPG compared to gasoline fuel. In injection vehicles, atomization of fuel inside the cylinder during spraying from inside the cylinder is very important. In this way, the fuel and air are ideally mixed and the combustion efficiency is improved. It is believed that liquid LPG sprayed from the injector compared to gasoline is a complete atomization and partially improves combustion, resulting in a reduction in $\mathrm{CO}$ emissions. In general, it is known that the $\mathrm{CO}$ emissions of vehicles with LPG are reduced. But in this study, spraying LPG in liquid form from the injector provided extra combustion efficiency and led to a reduction in $\mathrm{CO}$ emissions. The highest recovery rate was at $2000 \mathrm{rpm}$ with an engine speed of $66.6 \%$. The lowest recovery rate was achieved at an engine speed of $3500 \mathrm{rpm}$ with $12.5 \%$. 


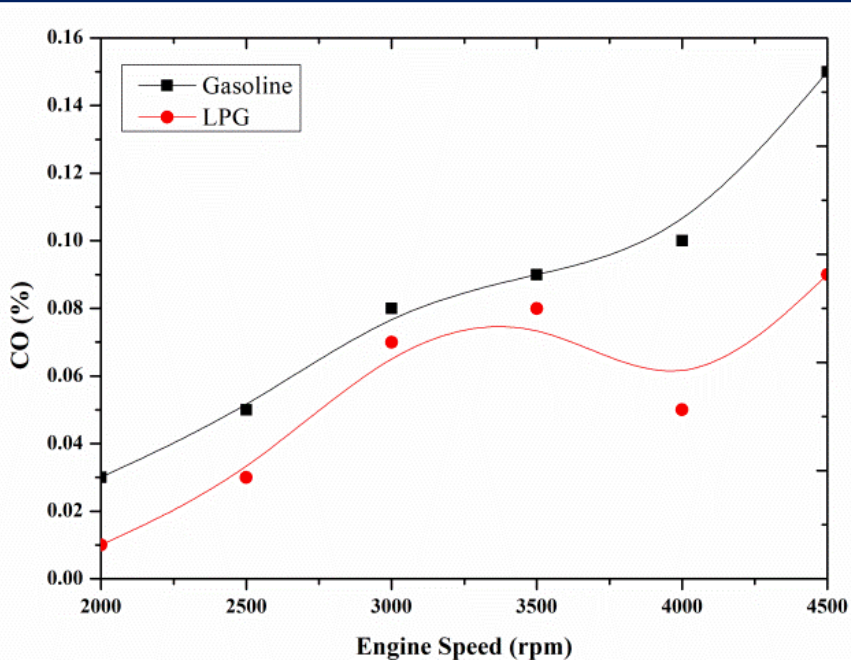

Figure 5. Change of $\mathrm{CO}$ emission.

Figure 6 shows the effect of changing the use of liquid LPG and gasoline according to engine speed on $\mathrm{CO}_{2}$ emissions. $\mathrm{CO}_{2}$ emissions as a result of full combustion of fuels with oxygen in the engine cylinder, $\mathrm{CO}$ emissions with incomplete combustion of remaining fuels after full combustion, $\mathrm{HC}$ emissions with the removal of fuel that does not burn at all from the exhaust [22, 23]. Along with liquid LPG, $\mathrm{CO}_{2}$ emissions tend to increase at engine speeds of 2000, 2500, 3000 and $3500 \mathrm{rpm}$. Engine speed 4000 and $4500 \mathrm{rpm}$ with the increase of the engine speed was seen to decrease. It is believed that combustion efficiency is higher with LPG, especially at low engine speeds, but with increasing engine speed, the combustion efficiency of liquid LPG decreases, thus causing a decrease in $\mathrm{CO}_{2}$ emissions [22, 24]. As the engine speed increases, more fuel is sent into the cylinder. In this way, the end-of-combustion temperature decreases with the heat drawn by LPG in the liquid phase from inside the cylinder. In this case, combustion efficiency tends to decrease. The highest reduction trend was achieved at an engine speed of $3000 \mathrm{rpm}$ with a rate of $13 \%$.

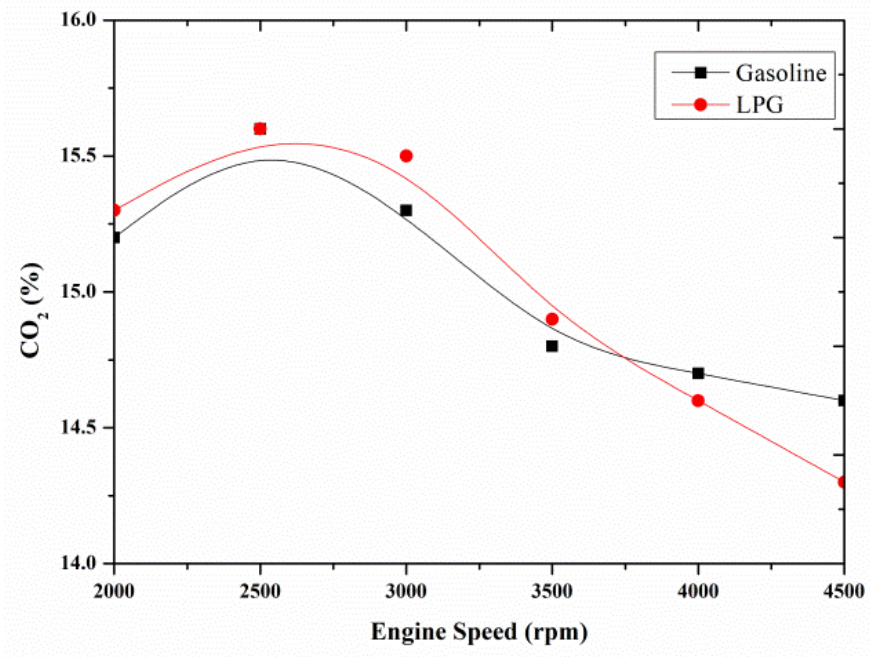

Figure 6. Change of $\mathrm{CO}_{2}$ emissions.

Figure 7 shows the effect of changing the use of liquid LPG and gasoline according to engine speed on $\mathrm{HC}$ emissions. $\mathrm{HC}$ emissions at all engine speeds have tended to decrease with the use of liquid LPG. With the use of liquid LPG, a similar HC emission profile was obtained with gasoline. The trend of reducing HC emissions is also an expected result in LPG vehicles with a classic system. The most positive result in terms of $\mathrm{HC}$ emissions was achieved with $26 \%$ of the engine speed at $3500 \mathrm{rpm}$. The lowest recovery rate was measured at $2000 \mathrm{rpm}$ with an engine speed of $15.7 \%$. Liquid LPG atomized by spraying from the injector is ideally mixed with air and increases combustion efficiency in terms of $\mathrm{HC}$ emissions have also been shown to give positive results. The results of the study are similar to those of [23-26] in the literature.

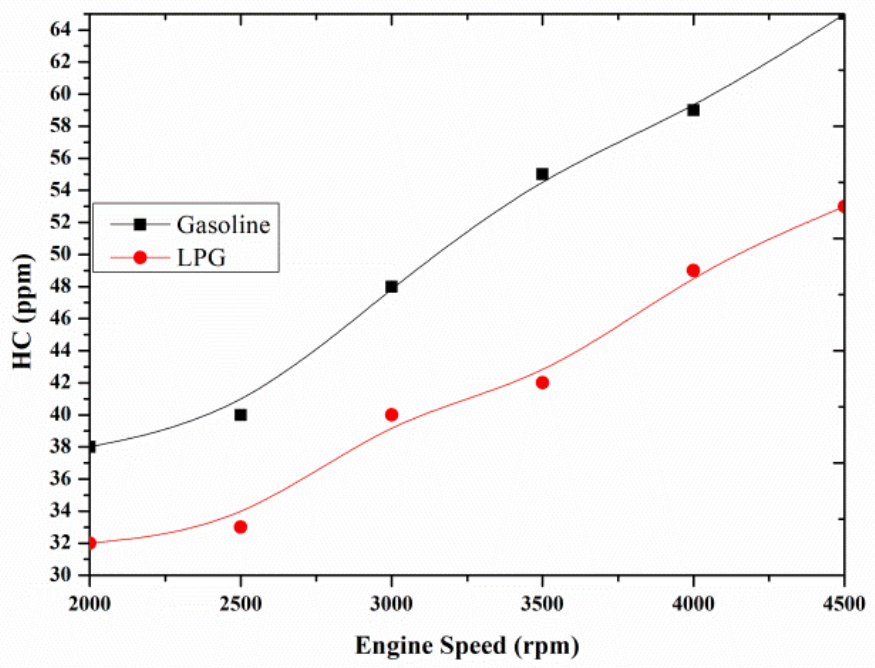

Figure 7. Exchange of HC emission.

Figure 7 shows the effect of changing the use of liquid LPG and gasoline according to engine speed on $\mathrm{O}_{2}$ emissions. In classic gasoline vehicles, gasoline is also taken when air passes through the carburetor and an ideal mixture is formed. A lack of oxygen in such engines would affect many combustion parameters and cause emissions to occur negatively. But today, it is known that the presence of oxygen in the cylinder can be adjusted with injector engines supported by turbochargers. In this way, many emissions are reduced. Octane number and flammability of LPG are one of the important features that lead to efficient combustion in this type of engine. At engine speeds of $2000 \mathrm{rpm}, 2500 \mathrm{rpm}$ and $3000 \mathrm{rpm}$, less oxygen from the exhaust also indicates that combustion has partially improved. But with the increase in engine speed, the oxygen content tended to increase with the use of liquid LPG. It is possible to express this condition by the fact that the combustion is partially worsened. 


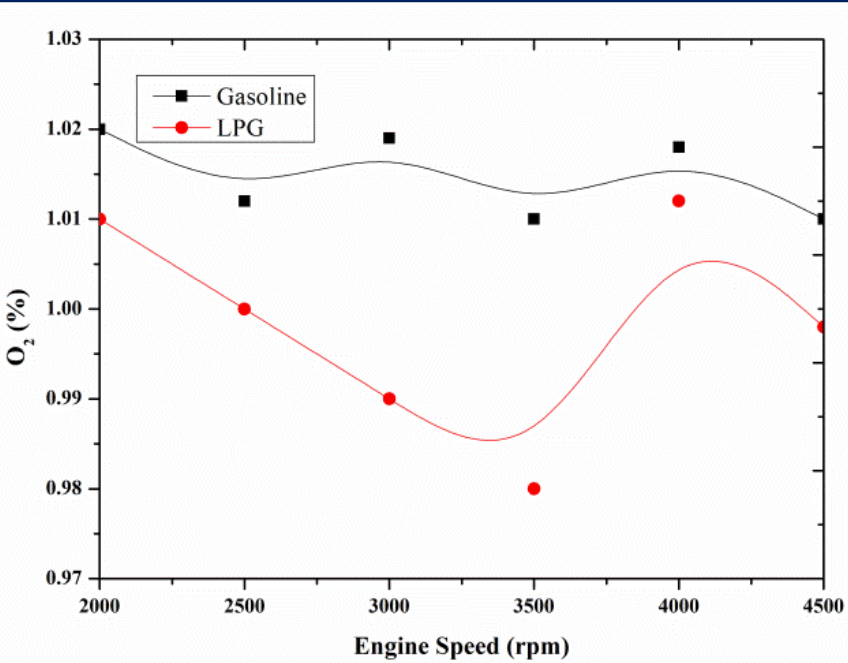

Figure 8. Change of $\mathrm{O}_{2}$ emission.

\section{Conclusion}

In this study, the effects of liquid LPG use on engine performance and exhaust emissions in vehicles with turbo direct gasoline injector (T-GDI) engine technology with liquid LPG system were determined. It was repeated at engine speeds of $2000 \mathrm{rpm}, 2500$ $\mathrm{rpm}, 3000 \mathrm{rpm}, 3500 \mathrm{rpm}, 4000 \mathrm{rpm}$, and $4500 \mathrm{rpm}$ while in gear lever position.

By using liquid LPG, an increase in engine power values is achieved at each engine speed. The highest increase rate was achieved at an engine speed of $4500 \mathrm{rpm}$. The maximum engine power is measured at $169 \mathrm{HP}$ with the use of liquid LPG, while this figure is reduced to $166 \mathrm{HP}$ with gasoline. An increase of approximately $1.7 \%$ in maximum engine power was achieved with the use of liquid LPG.

Engine torque increased slightly at engine speeds of $2500 \mathrm{rpm}$, $3000 \mathrm{rpm}$ and $3500 \mathrm{rpm}$ with the use of liquid LPG. If the engine speed is above $3500 \mathrm{rpm}$, it has shown a tendency to decrease again The highest increase rate is $210 \mathrm{Nm}$ of engine torque with liquid LPG at $2000 \mathrm{rpm}$, while under the same conditions; only $189 \mathrm{Nm}$ of torque was produced with gasoline. The highest reduction with liquid LPG was measured at an engine speed of $4500 \mathrm{rpm}$. The maximum engine torque was $268 \mathrm{Nm}$. $255 \mathrm{Nm}$ engine torque is produced with LPG under the same conditions. CO emission values are reduced compared to gasoline fuel operation mode in liquid LPG operation mode at all engine revs. The highest recovery rate was $66.6 \%$ with an engine speed of $2000 \mathrm{rpm}$, while the lowest recovery rate was $12.5 \%$ with an engine speed of $3500 \mathrm{rpm}$.

Along with the use of liquid LPG, there was an increase in $\mathrm{CO}_{2}$ emissions at engine speeds of 2000, 2500, 3000 and $3500 \mathrm{rpm}$, and with the increase in engine speed of 4000 and $4500 \mathrm{rpm}$, there was a decrease in $\mathrm{CO}_{2}$ emission values. When the Test results were examined, the highest reduction trend was realized at an engine speed of $3000 \mathrm{rpm}$ with a rate of $13 \%$.

Along with the use of liquid LPG at all engine speeds, there was a decrease in $\mathrm{HC}$ emissions compared to the use of gasoline. When
$\mathrm{HC}$ emission values were examined, the highest amount of reduction was achieved with $26 \%$ at 3500 rpm engine speed, while the lowest recovery rate was determined with $15.7 \%$ at $2000 \mathrm{rpm}$ engine speed.

With the use of liquid LPG, the amount of $\mathrm{O}_{2}$ decreased at 2000 rpm, $2500 \mathrm{rpm}, 3000 \mathrm{rpm}$ and $3500 \mathrm{rpm}$, while the engine speeds tended to increase at $4000 \mathrm{rpm}$ and $4500 \mathrm{rpm}$.

\section{Nomenclature

$\begin{array}{ll}\text { T-GDI } & : \text { Turbocharged g-Gasoline Direct Ignition } \\ \mathrm{HC} & : \text { hydrocarbon } \\ \mathrm{CO} & : \text { carbon monoxide } \\ \mathrm{NOx} & : \text { nitrogen oxides } \\ \mathrm{PM} & : \text { particulate matter } \\ \mathrm{CO}_{2} & : \text { carbon dioxide } \\ \mathrm{CI} & : \text { compression ignition engines } \\ \mathrm{SI} & : \text { spark ignition engines } \\ \mathrm{SO}_{2} & : \text { sulfur dioxide } \\ \mathrm{LPG} & : \text { liquefied petroleum gas } \\ \mathrm{CNG} & : \text { compressed natural gas } \\ \mathrm{LNG} & : \text { liquefied natural gas } \\ \mathrm{H}_{2} & : \text { hydrogen } \\ \mathrm{NEDC} & : \text { European Driving Cycle }\end{array}$

\section{Conflict of Interest Statement}

The authors declare that there is no conflict of interest in the study.

\section{CRediT Author Statement}

Salih ÖZER: Methodology, Project administration, Writing review \& editing

Bahtiyar Bağatur: Postgraduate, Writing - original draft

\section{References}

[1] Özer S, Vural E. Effects of CNG addition in a diesel engine using diesel / n-heptane, diesel/toluene as pilot fuel. Gazi University Journal Of Faculty Of Engineering. 2020;8(2):1-10.

[2] Yağız S. Investigation of the possibilities of using cottonseed oil and waste cottonseed biodiesel as fuel in a diesel-powered generator, Batman University Institute of natural and Applied Sciences, Master Thesis. (2019).

[3] Datta A. Mandal, BK. A comprehensive review of biodiesel as an alternative fuel for compression ignition engine, Renewable and Sustainable Energy Reviews. 2016;57:799-821.

[4] Özer S, Akçay M, Vural E. Effects of LPG use in a turbocharged stratified injection (TSI) engine using ethanol/gasoline as pilot fuel, Thermal Science. 2021;24(1):101-110.

[5] Özbay H, Közkurt C, Dalcalı A, Tektaş M. Transportation Choice Of The Future: Electric Vehicles. Journal of Intelligent. Transportation Systems and applications. 2020;3(1):34-50.

[6] Naik R, Babu M, Das L. Performance Studies on CNG Enriched with LPG Oprated Variable Speed Spark Ignition Engine, AJIRSET. 2018;1(3):1-6. 
[7] Karagöz Y, Sandalcı T, Yüksek L, Dalkılıç AS, Wongwises S. Effect of hydrogen-diesel dual-fuel usage on performance, emissions and diesel combustion in diesel engines, Advances in Mechanical Engineering. 2016;8(8);1-13.

[8] Organ B, Huang Y, Zhou JL, Surawski NC, Yam YS, Mok WC, Hong G. A remote sensing emissions monitoring programme reduces emissions of gasoline and LPG vehicles, Environmental research. 2019; 177:108614.

[9] Demirci O, Çınar C. HCCI-DI examination of the effect of natural gas use on performance and exhaust emissions in an engine. Gazi University Journal of Natural Sciences Part C: Design and Technology. 2019;7(2):317-330.

[10]Prins Autogas conversion systems, sequential system LPG, https://www.prins.com.tr/sirali-sistem-lpg, $2021 \quad$ [Access Date:12/04/2021].

[11]Lu G, Li L. Study on combustion parameters of liquefied petroleum gas engine, Energy Procedia. 2011;12:897-905.

[12]Karamangil MI. Development of the auto gas and LPG-powered vehicle sector in Turkey: A statistical case study of the sector for Bursa, Energy policy. 2007; 35 (1):640-649.

[13]Saputro W, Garcia P. Design and Performance of LPG Fuel Mixer for Dual Fuel Diesel Engine, E\&ES. 2018;147(1):1-22.

[14]Zhu G, Liu J, Fu J, Xu Z, Guo Q, Zhao H. Experimental study on combustion and emission characteristics of turbocharged gasoline direct injection (GDI) engine under cold start new European driving cycle (NEDC), Fuel, 2018;215:272-284.

[15]Kunt M. The Effect of LPG Application on Engine Performance and Exhaust, Journal of Thermal Engineering. 2019;5(9):58-69

[16]Beak S, Kim K, Cho J, Myung C, Park S. Assessment of gaseous, particulate, and unregulated emissions from diesel compression ignition and LPG direct injection spark ignition minibus vehicles under the world harmonized vehicle cycle on a chassis dynamometer, Fuel. 2021;294(2021):120392.

[17]Ahn S, Cho J, Baek S, Kim K, Ko, J, Myung CL, Park S. Comparative Investigation Of Gaseous Emissions And Particle Emission Characteristics From Turbo-Charged Direct Injection (Di) Engine With Gasoline And LPG Fuel Depending On Engine Control Parameters. International Journal of Automotive Technology, 2020;21(2): 451-457.

[18]Darzi M, Johnson D, Ulishney C, Clark N. Low pressure direct injection strategies effect on a small SI natural gas twostroke engine's energy distribution and emissions. Applied Energy, 2018;230(2018):1585-1602.

[19]Morganti KJ, Brear MJ, da Silva G, Yang Y, Dryer FL. The autoignition of Liquefied Petroleum Gas (LPG) in spark-ignition engines, Proceedings of the Combustion Institute. 2015;35(3):2933-2940.

[20]Vinoth T, Vasanthakumar P, Krishnaraj J, Arun S, Hariharan J, Palanisamy M. Experimental Investigation on LPG+Diesel Fuelled Engine with DEE Ignition Improver, Materials Today: Proceedings. 2017;4(8):9126-9132.

[21]Duc KN, Duy VN. Study on performance enhancement and emission reduction of used fuel-injected motorcycles using bio-fuel gasolineLPG, Energy for Sustainable Development. 2018; 43:60-67.

[22]Masi M. Experimental analysis on a spark ignition petrol engine fuelled with LPG. Energy. 2012;41(1):252-260.
[23]Jamali Q, Bhatti M, Qazi Q, Kaurejo B, Qazi I, Solangi S, Jamali A. Analysis of $\mathrm{CO}_{2}, \mathrm{CO}, \mathrm{NO}, \mathrm{NO}_{2}$, and PM particulates of a diesel engine exhaust, Engineering, Technology \& Applied Science Research. 2019;9(6):4912-4916.

[24]Kim K, Kim J, Oh S, Kim C, Lee Y. Lower particulate matter emissions with a stoichiometric LPG direct injection engine, Fuel, 2017; 187:197-210.

[25] Boretti A. Numerical study of the substitutional diesel fuel energy in a dual fuel diesel-LPG engine with two direct injectors per cylinder, Fuel Processing Technology. 2017;161:41-51.

[26]Nik RA, Hazimi I, Hazimi I, Zeno M, Zeno M, Hazim N. Emissions In An Air Cooled Gasoline Engine. Jurnal Teknology. 2015;76 (9):25-29 